\title{
Sample Profitability and Cost Estimates of Producing Sweet Carambola (Averrhoa carambola) in South Florida ${ }^{1}$
}

\author{
Fredy H. Ballen, Aditya Singh, Edward A. Evans, and Jonathan H. Crane ${ }^{2}$
}

\section{Introduction}

Carambola (Averrhoa carambola L.) is a member of the Oxalidaceae and is indigenous to Southeast Asian countries such as Malaysia, India, and Sri Lanka. It is best adapted to tropical climates but is productive in warm subtropical areas. The main global producers of carambola are Taiwan, Malaysia, Guyana, and India (Crane 2016).

In the United States, commercial carambola acreage is located in Florida, Hawaii, and the territory of Puerto Rico. The main carambola exporters to the US market include Taiwan, Thailand, and Mexico; fresh carambola is sold in selected US markets including Baltimore, Boston, Chicago, San Francisco, New York, Philadelphia, and Los Angeles. Carambola imports are available year-round (USDA AMS 2018).

The initial carambola introductions into Florida were about 100 years ago and were tart in flavor (Crane 2016). Florida's commercial carambola production is estimated at 150 acres and constitutes 90 percent of the carambola grown in the United States (Crane 2018). Sixty-seven percent of the total carambola acreage is in Lee County and about $27 \%$ in Miami-Dade County, with the rest of the production in Palm Beach and Broward Counties.
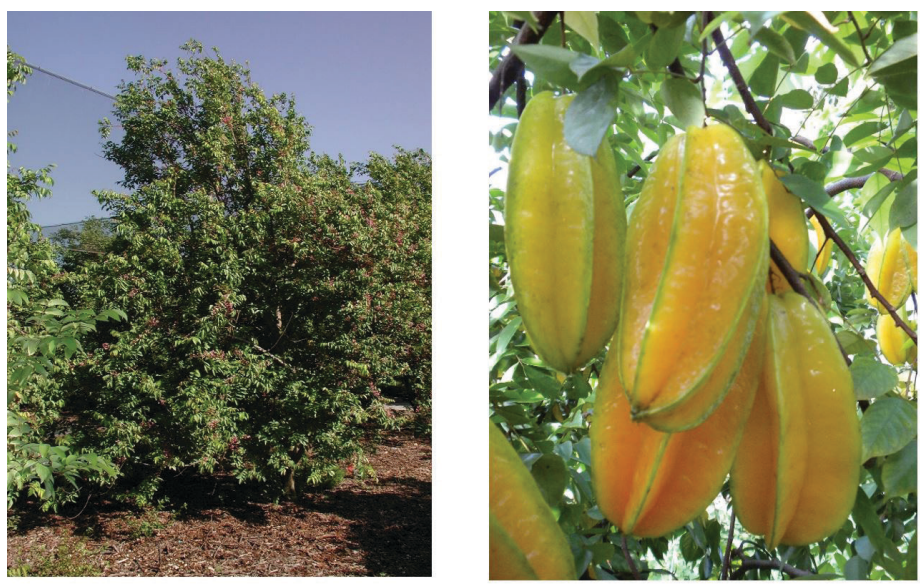

Figure 1. 'Arkin' carambola tree in flower and 'Kary' carambola fruit. Credits: Left I. Maguire, UF/IFAS; Right: J. Crane, UF/IFAS

Carambola trees are highly sensitive to windy and cold conditions; production and fruit quality benefit greatly from natural or man-made wind protection and growing sites with little to no cold or freezing temperatures (Crane 2016). There are two main types of carambola, i.e., sweet and tart. Sweet ones are generally savored as fresh fruits, and tart-flavored ones are generally used in the processed food industry. Major sweet carambola cultivars are 'Arkin' and 'Kary'. Minor cultivars include 'Fwang Tung' and 'B-10' (Cooper et. al. 2013; Crane 2016). Carambola has two harvest seasons. The first is from late June through

1. This document is FE1079, one of a series of the Food and Resource Economics Department, UF/IFAS Extension. Original publication date April 2020. Visit the EDIS website at https://edis.ifas.ufl.edu for the currently supported version of this publication.

2. Fredy H. Ballen, data management analyst Il; Aditya Singh, research scholar; Edward A. Evans, center director and professor, Food and Resource Economics Department; and Jonathan H. Crane, associate center director, professor, and tropical fruit crop specialist; UF/IFAS Tropical Research and Education Center, Homestead, FL 33031.

The Institute of Food and Agricultural Sciences (IFAS) is an Equal Opportunity Institution authorized to provide research, educational information and other services

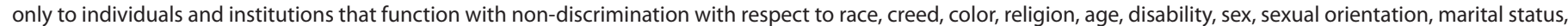

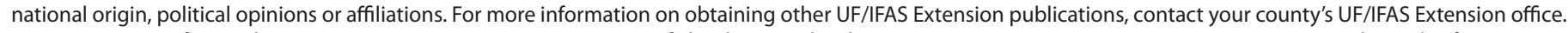
U.S. Department of Agriculture, UF/IFAS Extension Service, University of Florida, IFAS, Florida A \& M University Cooperative Extension Program, and Boards of County Commissioners Cooperating. Nick T. Place, dean for UF/IFAS Extension. 
September and the second from November into February (Crane 2016).

A mature tree (7 years or older) yields 250 to $350 \mathrm{lbs}$. of fruit per year, depending on the cultivar, prevailing climatic conditions, and cultural practices followed (Crane 2016). Assuming a planting density of 140 trees per acre, and a yield of $320 \mathrm{lbs}$. per tree, results on a yield estimated at 44,800 pounds per acre. Based on a fruit pack-out rate of $85 \%$, marketable yield is about 38,080 pounds per acre.

Hence, Florida carambola production is estimated at 5.7 million pounds ( 150 acres $^{\star} 38,080 \mathrm{lbs}$ ); at an average F.O.B. Homestead price (i.e., the price at the packing house) for carambola of $\$ 0.65 /$ pound, the crop is worth about $\$ 3.7$ million at the packinghouse level.

Because of the increasing interest in the profitability of alternative minor tropical fruit crops, this publication reports the costs and returns of operating an established carambola grove in south Florida. The information presented was collected through field interviews with growers and industry specialists, and it is based on a wide range of production practices in small farms (1-5 acres). The information presented in this document is intended only as a reference to estimate the financial requirements of running an already-established carambola grove. Readers interested in specific information related to cultural practices for carambola may want to refer to the fact sheet HS12, Carambola Growing in Florida Home Landscape (https://edis.ifas.ufl.edu/mg269).

\section{Main Assumptions}

Information about budget and cost of production per year of operation is based on a one-acre grove. Because of the varied types of cultural practices adopted, only the average cost and return values as reported by the surveyed growers are used for the present analysis. Given that most tropical fruit growers in south Florida own the land, a prevailing market rent of $\$ 500 /$ acre/year is taken into consideration to factor in the opportunity cost of the land. Table 1 shows the estimated total annual costs and returns associated with managing a one-acre carambola grove.

Orchard Layout-Under south Florida conditions, rows are spaced 20 to 25 feet and trees are spaced 15 to 20 feet in-row, resulting in a planting density ranging from 87 to 145 trees per acre (Mossler and Crane 2013). The present analysis considers a density of 140 trees/acre.
Orchard Infrastructure-Commercial carambola groves must be wind protected to be productive and produce high-quality fruit (Figure 2). Producers have two options. They may place their carambola grove within a natural wind break (e.g., bamboo hedge row, forest, or planted wind break, or inside a grove where mature older trees act as a border and wind break; sometimes intersect the grove), or they may establish a wind-protection structure $(\$ 40,000$ acre or more). Most smaller producers have used alreadyestablished natural wind breaks because they are much less expensive.

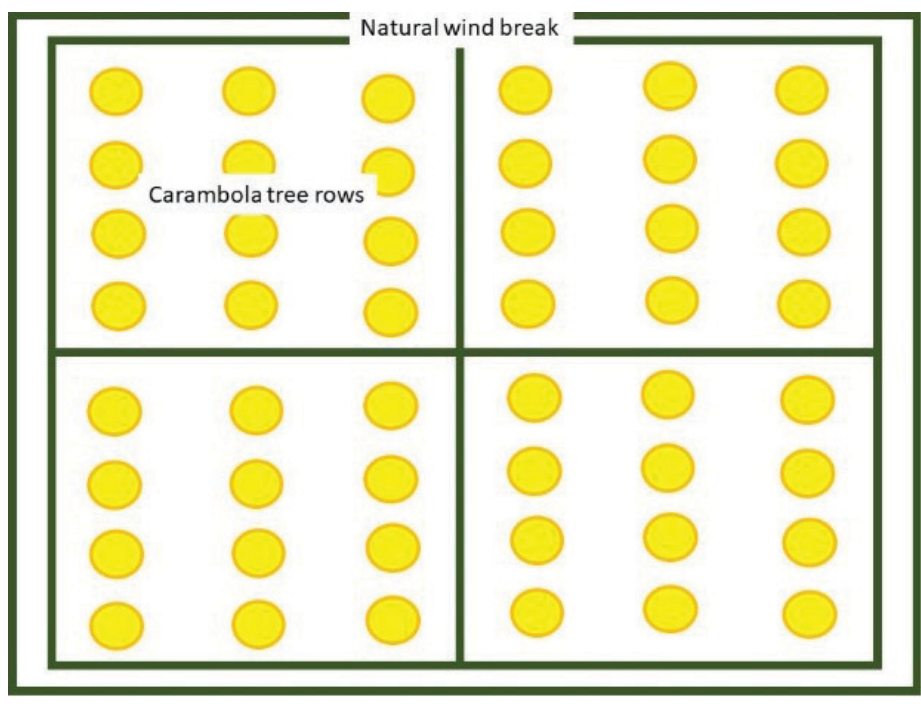

Figure 2. Carambola natural or man-made wind protection structure. Credits: J. H. Crane, UF/IFAS

Yields-On the basis of the information provided by the growers, average yield is estimated at 44,800 pounds/acre/ year. Considering a pack-out rate of $85 \%$, the result is an average marketable yield of 38,080 pounds/acre/year.

Carambola Prices-The average F.O.B. (Homestead) sweet carambola price (price at the packing house) is estimated at $\$ 0.65$ per pound. This is the average price growers received from the packing houses in 2017.

Irrigation-Mature carambola trees ( 7 years or older) should be watered regularly from flowering to the harvesting stage (Crane 2016). Average irrigation expenses comprised of fuel or electricity costs are estimated at $\$ 185 /$ acre/year.

Fertilization-The fertilizer program for mature carambola trees ( 7 years or older) is very intensive and includes applications of fertilizer mixtures containing $6 \%-8 \%$ nitrogen, $2 \%-4 \%$ available phosphorous, $6 \%-8 \%$ potash, and $3 \%-4 \%$ magnesium at a rate of $4 \mathrm{lbs} /$ tree averaging 4 times a year (Crane 2016). Also included are soil-drench applications of chelated iron at a rate of $4 \mathrm{oz}$./tree/year and minor nutrient foliar sprays (zinc and manganese) 6 times/tree/year. Some 
growers apply an 8-16-16 fertilizer mix along with chelated iron and minor nutrient sprays. Average fertilization costs (material only) are estimated at $\$ 1,000 /$ acre/year.

Pest Management-Some pests attack carambola, including stinkbugs (Nezara viridula and others), plumose (Morganella longispina), and philephedra (Philephedra tuberculosa) scales, which may cause damage to leaves and twigs. Infestation may lead to stem dieback and defoliation (Ooi et al. 2002; Crane 2016).

A number of diseases affect carambola, including red alga (Cephaleuros virescens), which causes shoot dieback, leaf spots (Cercospeora averrhoa and others), root rot (Pythrium splendens), and anthracnose on the fruit (Colletotrichum gloeosporioides) (Crane 2016).

Weed-management practices include herbicide applications, hand weeding, and mulching. Pests and diseases are controlled on an as-needed basis only. Weed control represents the major pest-control cost, estimated at $\$ 250$ / acre/year (materials only).

Labor Costs-These include costs to apply agricultural inputs and costs incurred for performing various cultural operations (e.g., irrigation maintenance, pruning, weed control, and mowing). Labor costs are estimated at $\$ 1,025$ / acre/year.

Interest on Capital-This is the cost of borrowing money or the opportunity cost for using equity. A rate of $5 \%$ was considered in the given analysis. It is estimated at $\$ 123$ / acre.

Fixed Costs-This constitutes the costs that are incurred regardless of the level of production. It includes cash overhead costs (e.g., insurance and taxes), non-cash overhead costs (e.g., land rent), and other overhead costs (e.g., machinery use, electricity, telephone, computer, and other miscellaneous office expenses). Total fixed costs are estimated at $\$ 1,550 /$ acre/year.

Harvesting and Marketing Costs-Carambola trees may have harvestable fruit nearly year round, though the main harvest season runs from June through February. Carambola fruits can be easily bruised; therefore, extra care must be exercised while harvesting. A carambola grove is generally harvested about 25-30 times a year (Crane 2016; Mossler and Crane 2013). The cost for picking, packing, and marketing carambola is estimated at $\$ 13,328$ /acre/year.
Table 1 shows the per-acre expenses and returns associated with a full production of a carambola grove.

Production Costs (or variable costs) - Production costs are estimated at $\$ 2,583$ (about $\$ 0.07$ per pound), representing $14.79 \%$ of the total cost. The major components from the production costs include hired labor $(40 \%)$, fertilizers (39\%), herbicides (10\%), and irrigation (7\%).

Fixed Costs-These include cash and non-cash overhead charges (e.g., electricity, telephone, etc.) and are estimated at $\$ 1,050$. Although growers own the land, the going rate of $\$ 500$ per acre for land rental is used to reflect the opportunity cost of the land. Including the land rental charge, total fixed costs are estimated at $\$ 1,550 /$ acre/year $(\$ 0.04 /$ pound), representing $8.88 \%$ of the total cost.

Harvesting and Marketing Costs-Harvesting and marketing costs are estimated at $\$ 13,328 /$ acre/year ( $\$ 0.35 /$ pound), representing $76.33 \%$ of the total cost. Sugar levels in carambola do not increase after harvest, and in order to have a desirable sweet flavor, the fruit need to be carefully harvested by hand during the "color break" stage, i.e., change in the color of the fruit from green to yellow at the base of the fins (Crane 2016; Mossler and Crane 2013).

Figure 3 illustrates the magnitude of the costs by category and their respective share of the total. Harvest and marketing costs are the major production expenses, accounting for $76.33 \%$ of the total cost, followed by cultural costs (variable costs for hired labor, irrigation, fertilization, and pest control), which constitute $14.09 \%$ of the total cost. Next are fixed or overhead costs at $8.88 \%$ of the total cost, and finally interest on capital at $0.70 \%$ of the total cost.

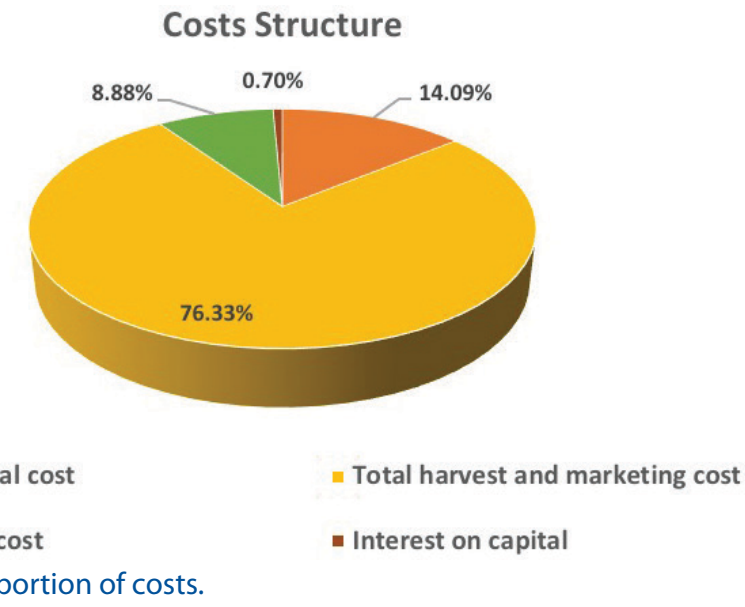

Figure 3. Proportion of costs. 


\section{Returns and Profitability Analysis}

The information provided in Table 1 shows that the total cost to produce and market one acre of carambola is estimated at $\$ 17,461 /$ acre/year ( $\$ 0.46 /$ pound). Based on an average marketable yield of 38,080 pounds/acre, and the average F.O.B Homestead price (at the packing house) of $\$ 0.65 /$ pound, the total receipt or gross revenue is $\$ 24,752$ / acre/year.

Subtracting total variable cost (total production cost plus harvesting and marketing cost) from total revenue, we obtain a gross margin of $\$ 8,841 /$ acre/year, or $\$ 0.23 /$ pound. The gross margin provides a useful indicator of short-term profitability. A positive gross margin indicates that all variable expenses have been met by the income generated, and some portion of fixed costs may be covered with the remaining additional funds.

A negative gross profit implies that a business is not economically feasible in the short term, and changes are needed to continue operating. Many growers are only concerned with the gross margin; however, while the gross margin provides an indication of return to the grower in the short run, it does not include fixed costs and, hence, is not a true assessment of the viability of the business in the long-term.

Net return is obtained by subtracting the fixed cost from the gross margin and is used to measure the long-term profitability of the farming operation. Table 1 shows a net return of $\$ 7,291 /$ acre/year, or $\$ 0.19 /$ pound, which exceeds significantly the economic return of other minor tropical fruit crops in the area.

\section{Sensitivity Analysis}

Table 2 presents an analysis based on gross margin (gross profit), which focuses on the short-term economic viability of a carambola grove operation. Under the best-case scenario, where both price and yield are assumed to increase by $10 \%$, gross margin per acre would increase from $\$ 8,841 /$ acre to $\$ 14,248 /$ acre. Under the worst-case scenario, where both price and yield decrease by $10 \%$, gross margin per acre would decrease from $\$ 8,841 /$ acre to $\$ 4,309 /$ acre. Price changes (keeping the production constant) have a smaller impact on gross margin compared to quantity changes (keeping the price constant). It can be observed that a $5 \%$ increase in the base price (base yield 38,080 pounds) has a smaller impact on gross margin ( $\$ 1,142$ more) than a $5 \%$ increase in yield (base price, $\$ 0.65 /$ pound, $\$ 1,238$ more). It must be noted that the gross margin estimates do not consider fixed costs.
Table 3 presents a similar analysis based on net returns to a grower on a per-acre basis. Under the best-case scenario where both price and yield are assumed to increase by $10 \%$, net return per acre would increase from $\$ 7,291 /$ acre to $\$ 12,698 /$ acre. Under the worst-case scenario, where both price and yield decrease by $10 \%$, net return per acre would decrease from $\$ 7,291 /$ acre to $\$ 2,759 /$ acre. Other combinations of changes of prices and yields and their impact on net return per acre are also shown in Table 3 . The information presented in Table 3 can be interpreted in a similar manner to that presented for Table 2. However, it should be noted that at the industry level a noticeable increase in production usually results in a decrease in the price received by the growers.

\section{Conclusions}

The average net return obtained from operating an established carambola grove in south Florida is $\$ 7,291 /$ acre, or $\$ 0.19 /$ pound, which makes this crop an interesting alternative to other minor tropical fruit crops grown in the area. However, it is important to consider the fact that the information showcased in this document refers only to the costs and returns associated with an established grove. We have not taken into consideration the financial aspects for establishing a new carambola grove, which includes creating, planting, or building a wind break, land acquisition and development, planting costs, amortized capital costs, etc.; therefore, the reader is advised to exercise caution when interpreting these results.

Desirable carambola fruit characteristics include smaller fins on the fruits, larger fruit size, and sweeter flavor. New cultivars and/or production practices that enhance those characteristics may increase demand for this fruit. Leading retail chains may be willing to pay a higher price for fruit with the above-mentioned attributes.

On the other hand, any sizable increases in carambola production may result in market saturation and downward pressure on prices. Contributing to increase the demand for carambola is the fact that carambola has been credited as one of the most multi-utility exotic fruits, having widespread uses in food service and tropical fruit wines. Additionally, the fruit has a low calorie content, and it is rich in polyphenolic flavonoids such as quercetin, epicatechin, and gallic acid, all of which have antioxidant properties (The grow network 2016). 


\section{References}

Cooper, A., S. Poirier, M. Murphy, M. J. Oswald, C.

Procise, A. Simonne, and L. B. Bobroff. 2013. South Florida

Tropicals: Carambola. FCS8520. Gainesville: University of Florida Institute of Food and Agricultural Sciences.

https://edis.ifas.ufl.edu/he613

Crane, J. H. 2018. "Tropical fruit production in Florida, trials, tribulations and opportunities." Proc. Fla. State Hort. Soc. 130:(accepted).

Crane, J. H. 2016. Carambola Growing in the Florida Home Landscape. HS12. Gainesville: University of Florida Institute of Food and Agricultural Sciences. https://edis.ifas. ufl.edu/mg269

Crane J. H. 1993. Commercialization of Carambola, Atemoya, and Other Tropical Fruits in South Florida. https:// hort.purdue.edu/newcrop/proceedings1993/V2-448.html

Mossler, A. M., and J. H. Crane. 2013. Florida Crop/Pest Management Profile: Carambola. CIR1416. Gainesville: University of Florida Institute of Food and Agricultural Sciences. https://edis.ifas.ufl.edu/pi056

Ooi, P. A. C., A. Winotai, and J. E. Peña. 2002. "Pests of minor tropical fruits." In Tropical Fruit Pests and Pollinators; Biology, Economic Importance, Natural Enemies and Control, edited by J. E. Peña, J. L. Sharp, and M. Wysoki. 315-330. New York, NY: CABI Publishing.

Sepiah, M., R.C. Ploetz, and S. W. Cooke. 2003. "Diseases of carambola." In Diseases of Tropical Fruit Crops. 145-162. New York, NY: CABI Pub.

The grow network. 2016. Star fruit-The sweet and the sour star of the tropics. http://thegrownetwork.com/ star-fruit-real-tropical-superstar/

USDA AMS. 2018. Agricultural Marketing Service. https://www.marketnews.usda.gov/mnp/ fv-report-config-step 1 ?type $=$ termPrice 
Table 1. Recurring cost per year of producing carambola on a south Florida one-acre orchard.

\begin{tabular}{|c|c|c|c|c|}
\hline \multicolumn{2}{|r|}{ Item } & Quantity (pounds) & Value per acre (\$/acre/year) & Value per pound (\$/pound) \\
\hline \multicolumn{5}{|l|}{ REVENUE } \\
\hline & Marketable yield (lbs./acre) & 38,080 & & \\
\hline & F.O.B. Homestead price & & & 0.65 \\
\hline & Total revenue & & 24,752 & \\
\hline \multicolumn{5}{|c|}{ PRODUCTION COSTS } \\
\hline & Irrigation & & 185 & \\
\hline & Fertilizer & & 1,000 & \\
\hline & Herbicide & & 250 & \\
\hline & Insecticide & & 0 & \\
\hline & Fungicide & & 0 & \\
\hline & Labor cost & & 1,025 & \\
\hline & Interest on capital (5\%) & & 123 & \\
\hline & Total production cost & & 2,583 & 0.07 \\
\hline \multicolumn{5}{|l|}{ FIXED COSTS } \\
\hline & Cash overhead: & & & \\
\hline & Insurance & & 100 & \\
\hline & Taxes & & 100 & \\
\hline & Noncash overhead: & & & \\
\hline & Land rent & & 500 & \\
\hline & Other overhead & & 850 & \\
\hline & Total fixed cost & & 1,550 & 0.04 \\
\hline \multicolumn{2}{|c|}{ TOTAL PRE-HARVEST COST } & & 4,133 & 0.11 \\
\hline \multicolumn{5}{|c|}{ HARVEST \& MARKETING COSTS } \\
\hline & Picking and sales cost & & 13,328 & 0.35 \\
\hline & Total harvest and marketing cost & & 13,328 & 0.35 \\
\hline \multicolumn{2}{|c|}{ TOTAL COST } & & 17,461 & 0.46 \\
\hline \multicolumn{2}{|c|}{ GROSS MARGIN } & & 8,841 & 0.23 \\
\hline \multicolumn{2}{|c|}{ ESTIMATED NET RETURN } & & 7,291 & 0.19 \\
\hline
\end{tabular}


Table 2. Sensitivity analysis, gross margin per acre.

\begin{tabular}{|c|c|c|c|c|c|c|c|}
\hline \multicolumn{2}{|c|}{ Yield (pounds/acre) } & \multicolumn{5}{c|}{ Wholesale Price (dollars/pound) } \\
\hline & & 0.59 & 0.62 & 0.65 & 0.68 \\
\hline & & $(-10 \%)$ & $(-5 \%)$ & $($ base) & $(+5 \%)$ & $(+10 \%)$ \\
\hline 34,272 & $(-10 \%)$ & 4,309 & 5,338 & 6,366 & 7,394 & 8,765 \\
\hline 36,176 & $(-5 \%)$ & 5,433 & 6,518 & 7,603 & 8,689 & 10,136 \\
\hline 38,080 & (base) & 6,556 & 7,699 & 8,841 & 9,983 & 11,507 \\
\hline 39,984 & $(+5 \%)$ & 7,680 & 8,879 & 10,079 & 11,278 & 12,877 \\
\hline 41,888 & $(+10 \%)$ & 8,803 & 10,060 & 11,316 & 12,573 & 14,248 \\
\hline
\end{tabular}

Table 3. Sensitivity analysis, net returns per acre.

\begin{tabular}{|c|c|c|c|c|c|c|}
\hline \multicolumn{3}{|c|}{ Yield (pounds/acre) } & \multicolumn{4}{c|}{ Wholesale Price (dollars/pound) } \\
\hline & & 0.59 & 0.62 & 0.65 & 0.68 \\
\hline & & $(-10 \%)$ & $(-5 \%)$ & $($ base) & $(+5 \%)$ \\
\hline 34,272 & $(-10 \%)$ & 2,759 & 3,788 & 4,816 & 5,844 \\
\hline 36,176 & $(-5 \%)$ & 3,883 & 4,968 & 6,053 & 7,139 \\
\hline 38,080 & (base) & 5,006 & 6,149 & 7,291 & 8,433 & 9,215 \\
\hline 39,984 & $(+5 \%)$ & 6,130 & 7,329 & 8,529 & 9,728 \\
\hline 41,888 & $(+10 \%)$ & 7,523 & 8,510 & 9,766 & 11,327 \\
\hline
\end{tabular}

